\title{
NOTE
}

\section{Black gut phenomenon in cardinal fishes (Apogonidae, Teleostei)}

\author{
L. Fishelson ${ }^{1, *}$, M. Goren ${ }^{1}$, O. Gon ${ }^{2}$ \\ ${ }^{1}$ Dept of Zoology, George S. Wise Faculty of Life Sciences, Tel-Aviv University, Ramat Aviv, 69978 Israel \\ ${ }^{2}$ J.L.B. Smith Institute of Ichthyology, PB 1015, Grahamstown 6140, South Africa
}

\begin{abstract}
A study of 78 species of cardinal fishes (Apogonidae) revealed that 22 of them had black guts, 5 species had partly black guts and, in 51 species, the digestive tube was unpigmented or had dispersed melanophores in the external tunic. The black pigmentation is caused by melanization of the submucosal connective tissue which is situated between the muscularis and the basal lamina of the internal epithelium. This phenomenon was previously observed in moray eels and some pelagic fish. In nocturnal predators, it appears to serve to conceal bioluminescent prey in the stomach cavity.
\end{abstract}

KEY WORDS: Apogonids - Melanization of guts

The occurrence of highly pigmented tissue in the abdominal cavity is one of the specific morphological characteristics of teleost fishes. This usually occurs in the form of melanization of the external gut tunic the extension of the somatopleural mesoderm that stains the abdominal cavity (Kent 1992). It has recently been demonstrated that in some species of moray eels, especially from deeper waters, dense melanization occurs within the connective tissue layer (tunica submucosa) between the muscularis and the mucotic epithelium of the gut-wall mucosa, producing partially or entirely black alimentary canals (Böhlke 1989, Fishelson 1994). A similar phenomenon was also discovered in Antarctic nototheniid fishes (Eastman \& De Vries 1997). The extent to which these black layers are developed differs among the various species of moray eels (Fishelson 1994). In some species the entire gut is black, and in others only the anterior parts. While studying the biology of cardinal fishes in the Gulf of Aqaba, Red Sea (Fishelson 1970, 1977), we observed for the first time that this family of fishes, too, features species with melanization of the alimentary canal. Fraser \& Struhsaker (1991), describing a new genus and species of

\footnotetext{
•E-mail: fishelv@ccsg.tau.ac.il
}

cardinal fish, Lachneratus phasmaticus, mention its 'blackish alimentary canal' as an identifying character. To study the distribution of this phenomenon in cardinal fishes (Apogonidae), we investigated 78 species of this family.

Methods. The material for this study included cardinal fishes preserved in collections of the Department of Zoology, Tel-Aviv University, Israel, as well as in the collection of the J.L.B. Smith Institute of Ichthyology, Grahamstown, South Africa. In addition, 18 species of live cardinal fishes were collected in the vicinity of Eilat, Gulf of Aqaba. For daytime collection we used quinaldin anesthetic, which we sprayed into the rock crevices used as hideouts by these fishes while, at night, underwater lights and hand nets were used. The collected fishes were sacrificed by an overdose of MS222, and their alimentary canals separated and fixed for light and electron microscopy (for methods see Fishelson 1994). In total, microsections from 20 fish were prepared. Macro cross-sections using a razor blade were studied in other fishes.

Results. Species of the genera Apogonichthys, Cheilodipterus, Foa, Siphamia and Sphaeramia did not possess melanized guts, while species with melanized guts were found in the genera Rhabdamia, Archamia and Apogon. In the latter genus, 25 species possessed black alimentary canals while 22 species had normal unpigmented guts (Table 1). It should be noted that in some of the cardinal fishes, such as Archamia mosambiquensis and Rhabdamia cypselurus, melanophores were found in the peritoneal lining enveloping the gut, giving it a dark, speckled appearance. In Apogon smithi and $A$. truncatus this peritoneal cover varied from black to pale and was unpigmented. In the species with black guts, the melanized connective tissue of the submucosa extended from the esophagus to the end of the hindgut (Fig. 1A, B), while in some species only part of the gut was melanized (Fig 1C). In Apogon leptacanthus the hindgut was not pigmented 


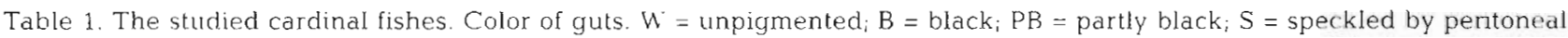
cells

\begin{tabular}{|c|c|c|c|c|c|c|c|c|}
\hline B & Apogon & angustatus & B & Apogon & lineatus & $\mathrm{S}$ & Archamia & lineolata \\
\hline W & Apogon & abrogramma & B & Apogon & maculiferus & $\mathrm{s}$ & Archamia & mozambiquensis \\
\hline B & Apogon & apogonides & W & Apogon & menesemus & W & Cheilodipterus & alleni \\
\hline B & Apogon & aureus & $\mathrm{B}$ & Apogon & multutaeniatus & W & Cheilodipterus & artus \\
\hline W & Apogon & carinatus & W & Apogon & natalensis & W & Chenlodipterus & intermedius \\
\hline W & Apogon & coccineus & $\mathrm{B}$ & Apogon & niger & W & Cheilodipterus & isostignuus \\
\hline B & Apogon & cookil & W & Apogon & nigripes & W & Cheilodipterus & lachnert \\
\hline W & Apogon & crassiceps & W & Apogon & aigripinnis & W & Cheilodipterus & arabicus \\
\hline B & Apogon & cyanosoma & $\mathrm{B}$ & Apogon & nigrofasciatus & W & Cheilodipterus & macrodon \\
\hline W & Apogon & darnleyensis & $B$ & Apogon & nititdus & W & Cheilodipterus & nigrotaeniatus \\
\hline B & Apogon & doderleini & B & Apogon & novaeguinae & W & Cheilodipterus & novemstriatus \\
\hline W & Apogon & doryssa & PB & Apogon & novemfasciatus & W & Cheilodipterus & parazonatus \\
\hline W & Apogon & erythrinus & B & Apogon & savayensis & W & Cheilodipterus & persicus \\
\hline B & Apogon & evermanni & W & Apogon & semiornatus & W & Cheilodipterus & pygmaios \\
\hline W & Apogon & exostigma & PB & Apogon & smithi & W & Cheilodipterus & quinquelineatus \\
\hline B & Apogon & fasciatus & $B$ & Apogon & striatus & W & Cheilodipterus & singapurensis \\
\hline B & Apogon & flagelliferus & W & Apogon & taeniatus & W & Cheilodipterus & zonatus \\
\hline B & Apogon & fleurieu & B & Apogon & taeniophorus & W & Foa & brachygramma \\
\hline W & Apogon & fraenatus & W & Apogon & thermalis & W & Fowleria & abocellata \\
\hline B & Apogon & guamensis & W & Apogon & timrorensis & W & Fowleria & isostigma \\
\hline$P B$ & Apogon & hungi & PB & Apogon & truncatus & W & Fowleria & variegata \\
\hline W & Apogon & imberbis & W & Apogon & wilsoni & $\mathrm{S}$ & Rhabdamia & cypselurus \\
\hline W & Apogon & kallopterus & W & Apogonichthys & ocellatus & W & Siphamia & mossambica \\
\hline W & Apogon & kalosoma & W & Apogonichthys & perdix & W & Siphamia & permutata \\
\hline W & Apogon & lateralis & PB & Archamia & dispilus & W & Sphaeramia & orbicularis \\
\hline B & Apogon & leptacanthus & $\mathrm{S}$ & Archamia & fucata & & & \\
\hline
\end{tabular}

and neither was the caeca in Apogon striatus. In all black guts the melanin tissue was situated between the muscularis within the submucosa and the mucosal epithelium (Fig. 2A, B), and frequently enveloped isolated bundles of muscles and nerves. At the base of the mucotic epithelial folds of the gut, this melanized tissue extended between the basal membranes of the juxtaposed epithelia into finger-like villi (Figs. 3 \& 4). Micrographs of this black tissue revealed that the melanin granules were irregularly rounded in form, 0.3 to $1.4 \mu \mathrm{m}$ in diameter, situated within melanophores of 20 to $24 \mu \mathrm{m}$ and often formed aggregates (Figs. $5 \& 6$ ). Some 6 to 7 layers of such cell aggregations were generally found densely packed between the other elements of this connective layer, as was also observed in the moray eels (Fishelson 1994). The thickness of this black coating varied from 160 to $240 \mu \mathrm{m}$ in different parts of the alimentary canal, with the thickest layers in the esophagus and stomach.

This unique pigmentation of the gut (and not of the peritoneum) which occurred in more then $40 \%$ of cardinal fish, compared with the pale gut of the other studied species, raises the same questions posed by Fishelson (1994) for moray eels: Why does such blackening of the submucosa occur only in some species of both morays and apogonids? Why does the same genus feature species both with and without melanized guts? In morays the black pigmentation is typical of deep-sea forms, and it has been postulated that these fish may specialize on bioluminescent prey, and that the black wall of the alimentary canal thus provides a shield pre- venting the predator from becoming luminous, and thereby becoming exposed to predators in its turn, until the shining prey has been digested.

Herring (1967), and recently Eastman \& De Vries (1997), suggested that the black peritoneum on the guts in some planktonic fish-larvae and oceanic fishes also serves the same purpose. A similar explanation could hold true for the cardinal fishes with black guts, despite being shallow water fish, assuming that they also prey on luminescent organisms. Underwater observations show that some species of cardinal fish are crepuscular in their foraging behavior; others are nocturnal foragers resting in the deeper coral-reef crevices during the day (Allen 1975, Vivien 1975). They include the species Apogon cyanosoma, A. cookii, A. angustatus, Archamia fucata and $A$. lineolata (Fishelson pers. obs.), all of which possess black guts. At night, bioluminescent planktonic organisms are plentiful, including the dense population of Noctiluca, shining euphausiids and mysids, and the lantern fish Photoblepharon palpebratus. On the other hand, species with unpigmented guts, such as those of the genus Cheilodipterus and some other cardinal fish, are crepuscular or diurnal, and were observed feeding during the late afternoon (Vivien 1975, Fishelson pers. obs.), but disappeared at night. Does this behavior mark the division between the species with black or white alimentary canals? The next stage of the study should examine the diets of the various cardinal fishes in order to determine the reason for this type of melanization of the alimentary canal in selected species. 


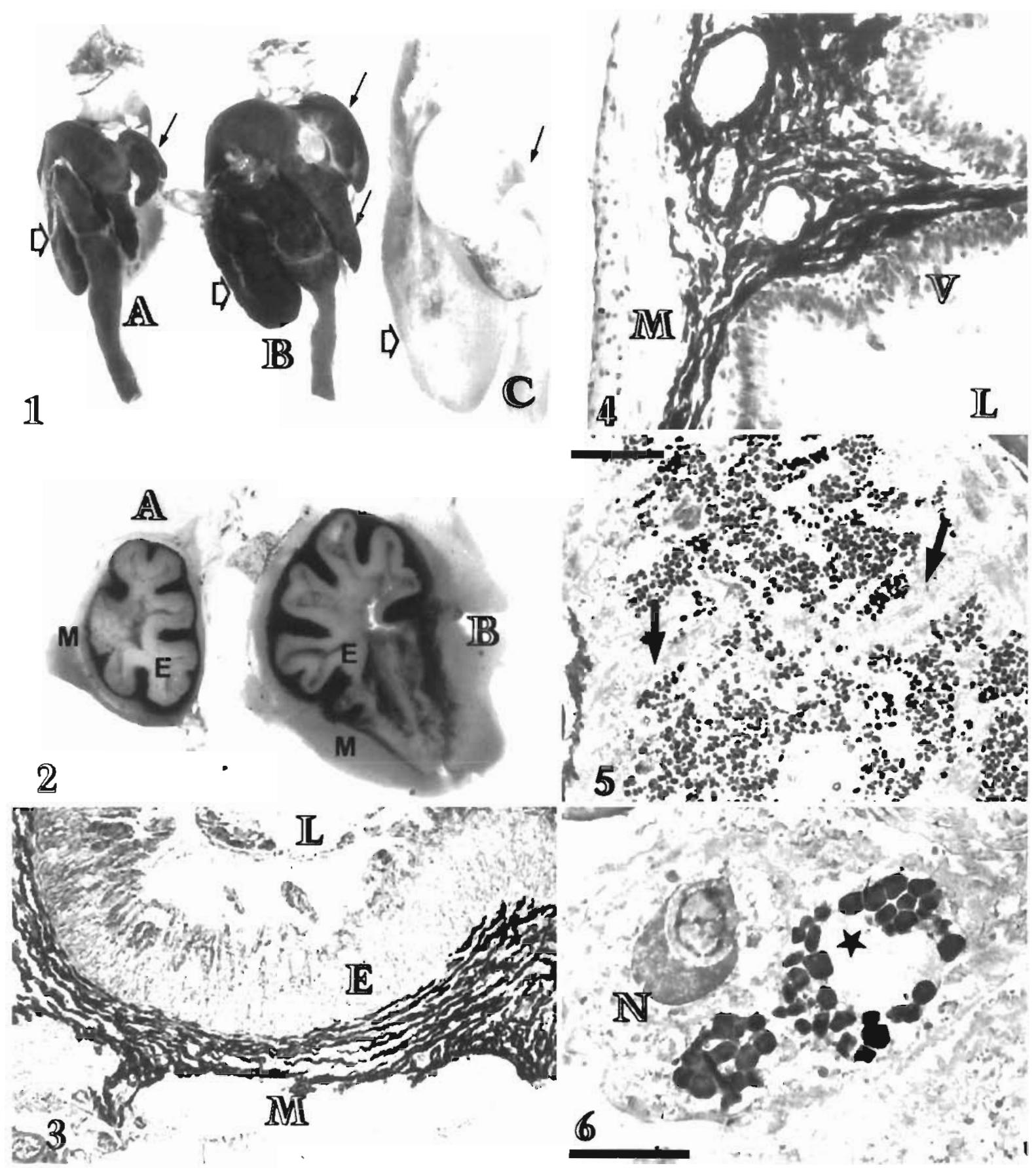

Figs. 1 to 6. Black gut phenomena in cardinal fishes. Fig. 1. Guts of apogonids. (A) Apogon doderlemi; (B) A. taeniophorus; (C) A. novaeguinae (stomach partly melanızed) (×4). Fig. 2. Macro cross-section of stomachs: (A) Archamıd dispilus; (B) Apogen evermanni $(\times 8)$. Fig. 3. Apogon cyanosoma. The layer of melanized tissue between the muscularis and mucosa in the intestinum $(\times 80)$. Fig. 4. Archamia lineolata. Penetration of melanized tissue into the villous mucosa $(\times 120)$. Figs. 5 \& 6 . Apogon cyanosoma. Granules of melanin dispersed and grouped in melanocytes (bar $=6 \mu \mathrm{m}$ ). E: endodermis (mucosal); L: lumen of gut; M: muscularis; N: nucleus of melanocyte; $V$ : villi of mucosal endodermis; thin arrow: coeca; open arrowheads: stomach; thick arrow: microfilaments of melanocytes; star: center of melanin production

\section{LITERATURE CITED}

Allen GR (1975) The biology and taxonomy of Sphaerama orbicularis (Pisces; Apogonidae). J R Soc West Aus 58(3) $86-92$
Böhlke EG (ed) (1989) Anguilliformes and Saccopharingiformes, Vol 1 In: Fishes of the Western North Atlantic. Sears Foundation for Marine Research. Allen Press, New York

Eastman JT, De Vries E (1997) Morphology of the digestive 
system of Antarctic nototheniid fishes. Polar Biol 17:1-13 Fishelson L (1970) Spawning behavior of the cardinal fish Cheilodipterus lineatus in Eilat (Gulf of Aqaba, Red Sea). Copeia 1970:370-371

Fishelson L (1977) Sociobiology of feedung behavior of coral fish along the coral reef of the Gulf of Eilat (Gulf of Aqaba), Red Sea. Israel J Zool 26:114-134

Fishelson L (1994) Comparative internal morphology of deepsea eels, with particular emphasis on gonads and gut structure. J Fish Biol 44:75-101

Editonal responsibility: Otto Kinne (Editor), Oldendorf/Luhe, Germany
Fraser TH, Struhsaker PJ (1991) A new genus and specles of cardinal fish (Apogonidae) from the Indo-West Pacific. with a key to Apogonine genera. Copeia 1991(3):718-722 Herring PJ (1967) The pigments of plankton at the seasurface. Aspects of marine zoology. Symp Zool Soc Lond $19: 215-235$

Kent GC (1992) Comparative anatomy of the vertebrates, 7 th edn. Mosby Year Book Inc, St. Louis, Toronto

Vivien ML (1975) Place of apogonid fish in the food webs of a Malagasy coral reef. Micronesica 11(2):185-198

Submitted: October 1, 1997, Accepted: October 28, 1997 Proofs received from author(s): December 22, 1997 